\title{
PROBLEMY MONITORINGU PRZEPLYWU ŚCIEKÓW I MIĄŻSZOŚCI OSADÓW W PRZEŁAZOWYCH KOLEKTORACH
}

\begin{abstract}
Celem artykułu jest uzasadnienie potrzeby włączenia pomiarów miąższości osadu kanałowego do monitoringu sieci kanalizacyjnej oraz przedstawienie i przeanalizowanie problemów technicznych związanych z prowadzeniem pomiarów przepływu ścieków i miąższości osadu w przełazowych kolektorach. Na podstawie analizy dostępnej literatury przedstawiono również obecne możliwe kierunki poprawy monitoringu osadu w sieci kanalizacyjnej. Artykuł zawiera analizę wpływu błędu pomiarowego miąższości osadu na estymację pola powierzchni przekroju poprzecznego osadu i ścieków. Na podstawie pomiarów w kolektorze grawitacyjnym o średnicy $1800 \mathrm{~mm}$ oceniono wpływ miąższości osadu dennego w kolektorze na jego sprawność hydrauliczną.
\end{abstract}

Słowa kluczowe: pomiary terenowe, współczynnik szorstkości, wzór Manninga, natężenie i prędkość przepływu, grubość osadu, niepewność pomiarowa

\section{Wstęp}

W ostatnich kilkunastu latach obserwowany jest szybki wzrost liczby wdrożonych w Polsce systemów monitoringu sieci kanalizacyjnych zintegrowanych w różnym stopniu z systemami GIS i modelami hydraulicznymi $[4,18]$. Systemy te nie uwzględniają pomiarów osadów kanalizacyjnych lub uwzględniają w stopniu nieproporcjonalnie małym $\mathrm{w}$ stosunku do wagi i skali problemu $[1,2]$. Zapewne jedną $\mathrm{z}$ przyczyn tego stanu są trudności $\mathrm{w}$ opomiarowaniu i eksploatacji systemu monitoringu oraz ilościowego opisu zjawisk powstawania i transportu zanieczyszczeń w systemach kanalizacyjnych.

Według Institute Francais de L'Environnement w samej Francji w 2008 roku większość kanałów o łącznej długości 373300 km było zagrożonych przez zgromadzone osady kanałowe, zaś w Wielkiej Brytanii oceniono, że $25000 \mathrm{~km}$ jest w znacznym stopniu zapełnionych osadami. W półmilionowym mieście Nantes (Australia) corocznie usuwanych jest 2000 t osadu z kolektorów o długo-

\footnotetext{
${ }^{1}$ Maciej Kalinowski, Przedsiębiorstwo Gospodarki Komunalnej Sp. z o.o., 05-091 Ząbki, ul. Piłsudskiego 2, tel.: (22) 781-68-18 wew. 259
} 
ści $134 \mathrm{~km}$ [8]. Z kolei według EBC (European Benchmarking Co - Operation) [7] jednym z kluczowych wskaźników niezawodności działania systemów kanalizacyjnych jest liczba zatorów w kanalizacji przypadających na $100 \mathrm{~km}$ w ciągu roku. W 2015 roku wartość tego wskaźnika w krajach UE zawierała się w szerokich granicach od 0 do 245 zatorów/100 km/rok przy medianie 40,9 zatorów/100 km/rok.

Monitoring uwzględniający opomiarowanie osadu w kanalizacji jest niezbędny do ograniczenia niekorzystnego odziaływania zrzutów burzowych na odbiorniki, do planowania zadań usuwania osadu, zapobiegania wylewiskom na powierzchnię zlewni, a także do racjonalnego rozliczania usług świadczonych przez firmy wodociągowo-kanalizacyjne na rzecz użytkowników systemów kanalizacyjnych.

Z powyższych spostrzeżeń wynika cel niniejszego artykułu, którym jest uzasadnienie potrzeby włączenia pomiarów miąższości osadu kanałowego do krajowego monitoringu sieci kanalizacyjnych oraz przedstawienie technicznych problemów związanych z prowadzeniem pomiarów przepływu ścieków i miąższości osadu w przełazowych kolektorach i zarysowania możliwości poprawy sytuacji w tym zakresie.

\section{Problematyka osadów kanałowych}

Zarządzanie osadem dennym w kolektorach jest jednym z głównych zadań eksploatacyjnych w przedsiębiorstwach wodociągowo- kanalizacyjnych.

Wymienić można podstawowe zagadnienia występujące w planowaniu strategii zarządzania osadami kanałowymi [20]:

- planowanie czyszczenia kanałów [20],

- projektowanie i instalowanie płuczek kanałowych [20],

- szacowanie i ograniczanie ryzyka wylewisk [20],

- ograniczenie częstości występowania zrzutów z przelewów burzowych [15],

- redukcja ładunku zanieczyszczeń związana ze zjawiskiem erozji osadów [15].

- ograniczenie emisji związków złowonnych emitowanych do powietrza atmosferycznego,

- zapewnienie odpowiednich warunków BHP dla pracowników eksploatujących sieci kanalizacyjne,

- dostarczenie danych do kalibracji i walidacji modeli hydraulicznych,

- dokonywanie rozliczeń między podmiotami zużytkowującymi dany system kanalizacyjny.

Do racjonalnego opracowania każdego $\mathrm{z}$ wymienionych zadań konieczna jest znajomość następujących, powiązanych między sobą parametrów [19]:

- natężenia i prędkości przepływu,

- napełnienia ściekami sieci kanalizacyjnej z osadem,

- miąższości i objętości osadu w funkcji czasu i przestrzeni, 
- własności fizycznych osadów,

- jakości ścieków.

W celu dokonania predykcji tych parametrów konieczne jest użycie modeli hydraulicznych poddanych kalibracji i walidacji.

\section{Pomiar natężenia przepływu}

W przypadku najczęściej stosowanych w kanalizacji metod ,,powierzchnia - prędkość" pomiar natężenia przepływu w kolektorze z osadem $Q_{s}(1 / \mathrm{s})$ jest pośredni i obliczany jest z równania ciągłości przepływu:

$$
Q_{s}=10^{-3} \cdot A_{3}\left(h_{s}\right) \cdot V_{s}
$$

gdzie: $\mathrm{A}_{3}$ - pole powierzchni przekroju czynnego strugi ścieków $\left[\mathrm{m}^{2}\right]$;

$\mathrm{V}_{\mathrm{s}}$ - pomierzona średnia prędkość $\mathrm{w}$ przekroju poprzecznym $[\mathrm{m} / \mathrm{s}]$;

$\mathrm{h}_{\mathrm{s}}-$ głębokość ścieków [m].

Generalnie brak jest uwarunkowań prawnych odnośnie dokładności pomiaru prędkości i przepływu ścieków [14]. Jedynie Dz.U. z 2014 poz.1800 w sprawie warunków, jakie należy spełnić przy wprowadzaniu ścieków do wód lub do ziemi oraz w sprawie substancji szczególnie szkodliwych dla środowiska wodnego przewiduje, że pomiaru natężenia przepływu ścieków komunalnych dokonuje się z dokładnością: 1) dla oczyszczalni ścieków o RLM poniżej 2000 - 15\%; 2) dla oczyszczalni ścieków o RLM od 2000 do 14999 - 10\%; 3) dla oczyszczalni ścieków o RLM od 15000 - 5 \%. Sytuacja taka oznacza brak możliwości określenia błędu pomiarowego przed zainstalowaniem i uruchomieniem przepływomierza oraz brak ustawowo zdefiniowanych sposobów sprawdzania dokładności [14].

W zaleceniach producentów przepływomierzy stawiany jest wymóg lokalizacji przepływomierzy na odcinkach kanałów bez osadów i zaburzeń pola prędkości, prostolinijnych, o stałym spadku dna kanałów na określonej ich długości w górę od przepływomierza [19, 20].

Z drugiej strony znane są wytyczne eksploatacyjne, które wymagają stosowania układów pomiarowych uwzględniających gromadzenie się osadów [24].

W praktyce spełnienie wszystkich wymogów oraz dotrzymanie dokładności pomiarowej deklarowanej przez producentów jest rzadko możliwe do zrealizowania, co może powodować rezygnację ze stosowania przepływomierzy i wywoływać związane z tym problemy eksploatacyjne.

Jeśli nawet założyć, że w chwili zainstalowania wszystkie te wymogi zostały spełnione, to później, w czasie eksploatacji, warunki przepływu mogą się niekorzystnie zmienić $\mathrm{w}$ stosunku do warunków producenta spełnionych w chwili zainstalowania przepływomierza, wpływając na pogorszenie jego charakterystyki metrologicznej. 
Bertrand-Krajewski [2] szacuje błędy pomiarowe natężenia przepływu w sieciach kanalizacyjnych dochodzące do +/-50 do +/- 100\% wskutek zaniechania lub niewłaściwej kalibracji i weryfikacji przepływomierzy oraz wadliwie dobranych i zlokalizowanych czujników pomiarowych.

\section{Pole powierzchni przekroju osadu i ścieków}

Pole powierzchni przekroju osadu oraz przekroju czynnego strugi ścieków (rys.1) obliczane jest ze wzorów trygonometrycznych (2-7).

$$
\begin{aligned}
& \alpha_{1}=2 \cdot \arccos \left(1-2 \cdot \frac{h_{o S}}{D}\right) \\
& \alpha_{2}=2 \cdot \arccos \left(1-2 \cdot \frac{h_{o S}}{D}-2 \cdot \frac{h_{s}}{D}\right) \\
& \alpha_{3}=2 \cdot \arccos \left(1-2 \cdot \frac{h_{s b}}{D}\right) \\
& \mathrm{A}_{1}=\left(0,125 \cdot D^{2}\right) \cdot\left(\alpha_{1}-\sin \alpha_{1}\right) \\
& A_{2}=\left(0,125 \cdot D^{2}\right) \cdot\left(\alpha_{2}-\sin \alpha_{2}\right) \\
& A_{3}=A_{2}-A_{1}
\end{aligned}
$$

gdzie: $\alpha_{1}$ - kąt środkowy szerokości osadu [rad];

$\alpha_{2}$ - kąt środkowy szerokości zwierciadła scieków w kolektorze z osadem [rad];

$\alpha_{3}$ - kąt środkowy szerokości zwierciadła scieków w kolektorze bez osadu [rad];

$A_{1}$ - pole powierzchni przekroju poprzecznego osadu [m²];

$A_{2}$ - pole powierzchni przekroju poprzecznego osadu i ścieków $\left[\mathrm{m}^{2}\right]$;

$h_{o s}$ - miąższość osadu [m];

$h_{s}$ - głębokość napełnienia ściekami [m];

$D$ - średnica kolektora [m];

$A_{3}$ - pole powierzchni przekroju poprzecznego ścieków $\left[\mathrm{m}^{2}\right]$.

Ponieważ sonda do pomiaru napełnienia nie może być przesłaniana przez osad, lokalizowana jest zwykle w najwyższym punkcie na stropie kolektora. Stąd pomiar napełnienia ściekami $h_{s}$ w kolektorze o przekroju kołowym jest realizowany pośrednio poprzez obliczanie ze wzoru:

$$
h_{s}=D-h_{p}-h_{o s}
$$

gdzie: D - pomierzona średnica wewnętrzna kolektora [m];

$\mathrm{h}_{\mathrm{p}}$ - pomierzona odległość między zwierciadłem ścieków a najwyższym punktem na stropie kolektora $[\mathrm{m}]$;

$\mathrm{h}_{\text {os }}-$ grubość osadu [m]. 


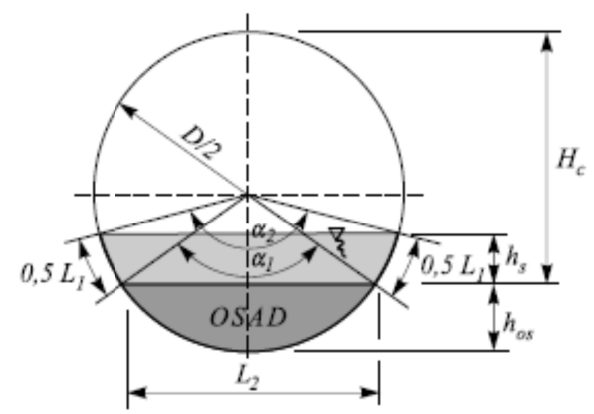

Rys. 1. Przekrój poprzeczny kolektora z osadem

Fig. 1. Cross section of sewer pipe with sediment

Ze wzorów (1-8) wynika, że parametrami wpływającymi na niepewność pomiarową pola powierzchni przekroju poprzecznego jest miąższość osadu oraz pomiar od góry do zwierciadła ścieków. Należy dodać, ze niekorzystny wpływ na dokładność i niezawodność pomiarów $h_{s}$ dokonywanych „od góry przez powietrze" wywiera piana i kożuchy oraz ciała stałe gromadzące się na powierzchni ścieków.

Rutynowe pomiary miąższości osadu wykonywane są manualnie przy pomocy stalowego pręta z ostrym zakończeniem, na który nasunięty jest przesuwny kołnierz. Pręt wprowadzany jest pionowo przez osad do dna kanału, zaś kołnierz przesuwany jest do powierzchni osadu. Miejscem pomiaru są zazwyczaj studnie i komory na sieci kanalizacyjnej. W badaniach naukowych pomiar miąższości odbywa się podobnie, lecz z większą częstością dostosowaną do występowania zjawisk przepływowych w kanale [1].

Manualną metodę pomiarową charakteryzuje szereg zasadniczych wad i ograniczeń wynikających nie tylko z przyjętej metody prowadzenia pomiarów, lecz również z bardzo trudnych i niebezpiecznych warunków pracy w kanałach i konieczności zachowania zasad BHP:

- wysoka niepewność pomiarów,

- niewielka częstość wykonywania pomiarów,

- niemiarodajna do oceny miąższości osadu lokalizacja punktów pomiarowych,

- brak ciągłości pomiarów,

- brak możliwości ustalenia profili poprzecznych i podłużnych osadu podczas przepływów generowanych opadami,

- zagrożenie dla zdrowia i BHP osób prowadzących pomiary.

Niepewność pomiarową metody manualnej oszacowania pola powierzchni przekroju poprzecznego osadu i pola powierzchni przekroju poprzecznego oszacowano metodą numeryczną ,min- max” [10]. 
Niepewność pomiarowa powierzchni przekroju poprzecznego osadu lub ścieków jest w tym przypadku powodowana błędem pomiaru miąższości osadu i obliczana jest $\mathrm{z}$ równań (2-5).

Zakładając błąd pomiaru miąższości osadu $\Delta h_{o s}=+/-0,03 \mathrm{~m}$ oraz pomiaru od góry położenia zwierciadła ścieków $\Delta h_{p s}=+/-0,005 \mathrm{~m}$ oszacowano przedziały zmienności niepewności pomiarowych pola powierzchni przekroju osadów (rys. 2) oraz pola powierzchni przekroju ścieków (rys. 3) w zależności od miąższości osadu $h_{o s}$ oraz głębokości ścieków $h_{s}$.

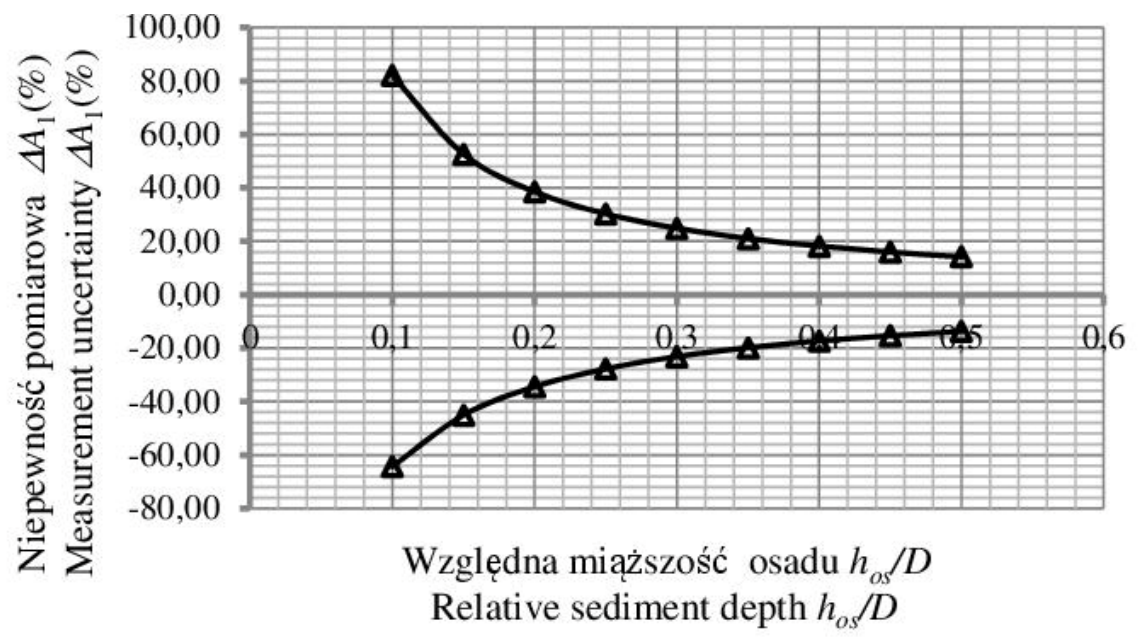

Rys. 2. Niepewność pomiarowa pola powierzchni przekroju poprzecznego osadu $\Delta A_{1}$

Fig. 2. Measurement uncertainty of sediment cross section area $\Delta A_{1}$

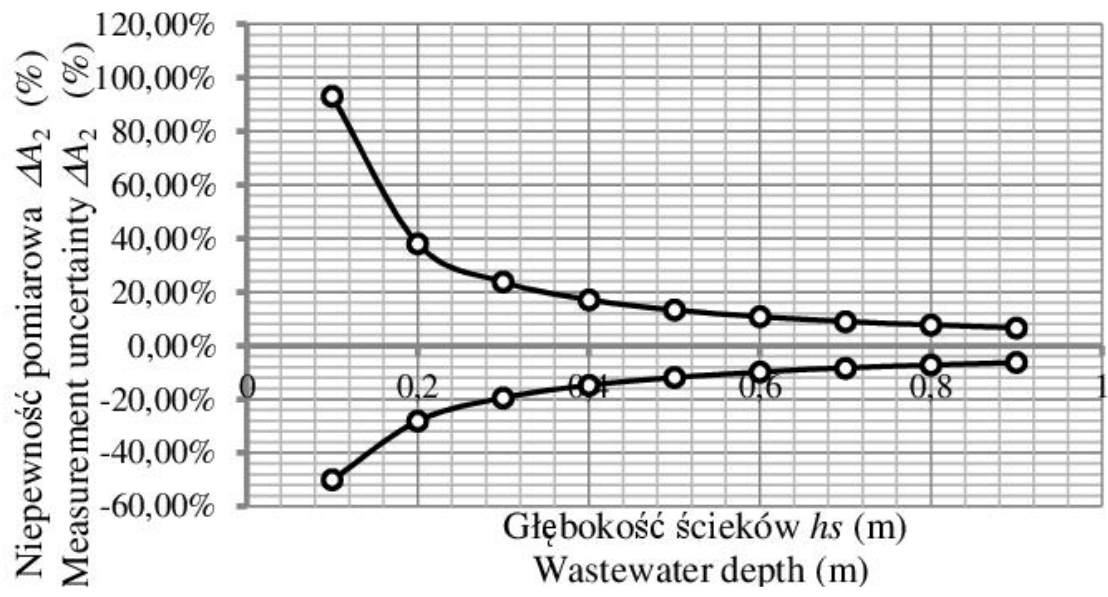

Rys. 3. Niepewność pomiarowa pola powierzchni przekroju poprzecznego osadu $\triangle A_{2}$

Fig. 3. Measurement uncertainty of sediment cross section area $\Delta A_{2}$ 
Oszacowane, wyżej wymienione niepewności pomiarowe (rys. 2, 3) są wyższe $\mathrm{w}$ przedziale głębokości $5-10 \mathrm{~cm}$ i zbliżone $\mathrm{w}$ przedziale głębokości $60-80 \mathrm{~cm}$ od/do niepewności pomiarowych natężenia przepływu określonych przez Nagańskiego I. dla kanałów jajowych bez osadu [13].

\section{Pomiar prędkości przepływu}

Pomiar średniej prędkości przepływu ścieków w kolektorach grawitacyjnych o swobodnym zwierciadle ścieków odbywa się zazwyczaj metodą ultradźwiękową[14, 23, 24].

Jednym z głównych warunków prawidłowej lokalizacji przepływomierza jest zapewnienie pola prędkości w przekroju pomiarowym zbliżonego do symetrycznego $[1,8,23]$. W rzeczywistości wymóg taki nie jest zawsze spełniony.

Wpływ na rozkład pola prędkości, a co za tym idzie na wartość średniej prędkości mają takie czynniki, jak [13]: zmiana geometrii przekroju poprzecznego i podłużnego ścieków czynnego wskutek lokalnego nagromadzenia się osadu i ciał stałych (,dead dogs”), dopływów bocznych, nadmiernych zmian kierunków trasy kanału i spadku dna, zmienna szorstkość ścian kanału i powierzchni osadu, fale stojące, odskok hydrauliczny, błąd ustawienie czujnika prędkości.

Stevens [16] przytacza test wykonany przez Environmental Technology Verification (ETV- EPA) w czynnym kolektorze. Wyniki tego testu wykonanego w dwóch sąsiednich przekrojach pomiarowych i przedstawione na wykresach „napełnienie/prędkość” wskazują na pojawienie się odskoku hydraulicznego, który spowodował wysoki $25 \%$ błąd pomiarowy natężenia przepływu.

Ciekawych danych odnośnie wpływu różnych zaburzeń pola prędkości przepływu dostarczyły badania rozkładu prędkości wykonane przez Kouyi [9] dla kanałów betonowych o średnicy $1,5 \mathrm{~m}$. Posługując się programami CFD-Ansys CFX12 i Ansys Fluent 13 autor wykonał symulacje numeryczne dla różnych wartości współczynnika heterogeniczności pola prędkości $\left(I_{x}\right)$ i relacji szerokości swobodnego zwierciadła ścieków do odległości $(X)$ od miejsca osobliwości. Wyniki obliczeń wykazały, iż w przypadku zaburzeń przepływu wywołanych zmianą kierunku przepływu ścieków o $45^{\circ}$ wystąpiły trzy kolejne strefy przepływu poniżej lokalizacji tych zaburzeń: strefa silnej heterogeniczności przepływu $\left(-4<I_{x}<10\right)$ o długości $0-20 B$, strefa przejściowa o długości $20 B-60 B$ i strefa quasi symetrycznego przepływu $\left(I_{x}<2\right)$ o długości $60 B-90 B$, gdzie $B$ jest szerokością swobodnego zwierciadła ścieków. Symulacja ujawniła również silną zależność współczynnika heterogeniczności od względnego napełnienia $h_{s} / D$ w strefie heterogeniczności i przejściowej. 


\section{Kierunki usprawnienia monitoringu}

W celu zwiększenia dokładności i zakresu pomiaru miąższości osadu opracowano szereg prototypowych urządzeń pomiarowych [20], których generalną charakterystykę zamieszczono w tabeli 1 .

Tabela 1. Ocena różnych systemów pomiarowych miąższości osadu

Table 1. Evaluation of different sediment depth measurement systems

\begin{tabular}{|c|c|c|c|c|c|c|c|}
\hline $\begin{array}{c}\text { Metoda } \\
\text { pomiarowa }\end{array}$ & $\begin{array}{c}\text { Elementy } \\
\text { pomiarowe }\end{array}$ & 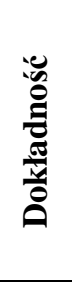 & שี & 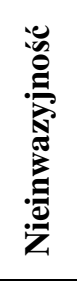 & 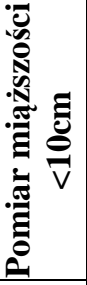 & 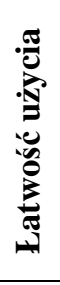 & 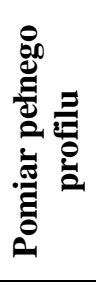 \\
\hline $\begin{array}{c}\text { Fal } \\
\text { ultradźwiękowych }\end{array}$ & $\begin{array}{c}\text { Sonar } \\
\text { ultradźwiękowy } \\
\text { podwodny }\end{array}$ & - & +++ & +++ & - & ++ & +++ \\
\hline $\begin{array}{l}\text { Podwodnego } \\
\text { skaningu }\end{array}$ & $\begin{array}{l}\text { Czujnik laserowy } \\
\text { podwodny }\end{array}$ & +++ & - & +++ & + & ++ & +++ \\
\hline Wizualizacji & Kamera podwodna & - & + & +++ & + & ++ & +++ \\
\hline $\begin{array}{l}\text { Geometryczna, } \\
\text { Miąższość osadu } \\
\text { jest obliczana } \\
\text { w funkcji konta } \\
\text { rozwarcia ramion }\end{array}$ & $\begin{array}{l}\text { Dwa ramiona } \\
\text { połączone przegu- } \\
\text { bowo, z których } \\
\text { koniec górnego } \\
\text { ramienia oparty jest } \\
\text { na sklepieniu kana- } \\
\text { łu a dolny na po- } \\
\text { wierzchni osadu }\end{array}$ & ++ & + & - & ++ & - & - \\
\hline
\end{tabular}

Wszystkie wymienione w tabeli 1 urządzenia mogą pracować zarówno jako stacjonarne, dokonując pomiarów profilu poprzecznego miąższości osadu, lub w układzie mobilnym, wykonując pomiary zarówno profilu poprzecznego, jak i podłużnego, w funkcji czasu. W tym ostatnim przypadku jako najkorzystniejsze urządzenia wymuszające ruch urządzeń wzdłuż kolektorów uznano pływaki i robot na kołach nienaruszający struktury i kształtu osadu.

\section{Sprawność hydrauliczna kolektorów}

Sprawność hydrauliczną danego odcinka kolektora z osadem dennym można określić jako przepustowość tego kolektora odniesioną do przepustowości tego samego kolektora lecz pozbawionego osadu. W związku z tym, posługując 
się wzorem Manninga, oceniono wpływ osadu na sprawność hydrauliczną kolektora całkowicie napełnionego przy pomocy równania (9):

$$
\eta_{h}=\eta_{g} \eta_{n}
$$

gdzie: $\eta_{h}$ - sprawność hydrauliczna kolektora z osadem dennym [-];

$\eta_{g}$ - współczynnik geometryczny; $\eta_{g}=\frac{R_{h o s}{ }^{2 / 3}}{R_{h o}{ }^{2 / 3}} \frac{A_{O S}}{A_{\mathrm{o}}}[-]$;

$\eta_{n}-$ współczynnik wpływu szorstkości; $\eta_{n}=\frac{n_{\mathrm{o}}}{n}[-]$;

$R_{h o s}$ - promień hydrauliczny przekroju czynnego kolektora z osadem o napełnieniu ściekami $h_{s}[\mathrm{~m}]$;

$R_{h o}$ - promień hydrauliczny przekroju czynnego kolektora bez osadu [m];

$A_{o s}$ - pole powierzchni przekroju czynnego kolektora z osadem o napelnieniu ściekami $h_{x}\left[\mathrm{~m}^{2}\right]$

$A_{\mathrm{o}}$ - pole powierzchni przekroju czynnego kolektora bez osadu $\left[\mathrm{m}^{2}\right]$;

$n$ - współczynnik oporów w kolektorze z osadem dennym $\left[\mathrm{s} / \mathrm{m}^{1 / 3}\right]$;

$n_{\mathrm{o}}-$ współczynnik oporów w kolektorze bez osadu $\left[\mathrm{s} / \mathrm{m}^{1 / 3}\right]$.

Tak określona sprawność jest jednocześnie miarą wpływu osadu dennego na sprawność hydrauliczną kolektora.

\section{Stanowisko pomiarowe}

Pomiary ciągłe natężenia i prędkości przepływu prowadzono w przedsiębiorstwie PGK w Ząbkach przy użyciu przepływomierza ultradźwiękowego OCM PRO CF produkcji firmy Nivus $\mathrm{z}$ dwiema sondami do pomiaru prędkości usytuowanych symetrycznie po obu stronach kolektora na tej samej wysokości 5-10 cm nad osadem. Pomiar prędkości odbywał się w interwałach 5 min metodą ultradźwiękową za pomocą korelacji krzyżowej (wzajemnej). Zsynchronizowany z pomiarem prędkości pomiar napełnienia ściekami dokonywany był sondą ultradźwiękową od góry przez powietrze. Deklarowana przez producenta przepływomierza dokładność pomiarowa w kolektorze bez osadu:

- prędkość: $1 \%$ zakresu pomiarowego lub $+/-0,03 \mathrm{~m} / \mathrm{s}$,

- napełnienie: $0,35 \%$ zakresu pomiarowego lub $+/-3 \mathrm{~mm}$.

Głębokość osadu mierzona była manualnie metodą opisana w rozdziale 4.

Kolektor został wykonany w latach 1987 r. z rur betonowych Wipro łączonych na pióro-wpust.

Do kolektora dopływają ścieki miejskie ze zdecydowaną przewagą bytowo-gospodarczych oraz odprowadzane są odpływy ze stacji zlewnej. W czasie opadów następuje dopływ do kolektora wód opadowych dynamizujących transport osadów. 
W kolektorze na całej jego długości od wielu lat zdeponowany jest osad. Awaryjnie dochodziło do okresowego zablokowania przepływu przez zgromadzone osady.

W dolnym, końcowym odcinku miąższość osadu była względnie niewielka i wahała się w trakcie prowadzonych pomiarów od $31 \mathrm{do} 41 \mathrm{~cm}$.

Osad denny wykazuje dużą konsolidację i odporność na mechaniczne usuwanie.

\section{Analiza wyników}

Wartości współczynników oporu „n” w kolektorze z osadem obliczono ze wzoru Chezyego przyjmując „C” według Manninga:

$$
n=\frac{R_{h}^{2 / 3} J^{1 / 2}}{V_{S}}
$$

W powyższym wzorze (10) średnia prędkość przepływu $V s$ i spadek hydrauliczny $J$ zostały określone w wyniku bezpośrednich pomiarów w czynnym kolektorze, zaś promień hydrauliczny $R_{h}$ obliczono przy pomocy wzoru trygonometrycznego. Można sądzić, że tak uzyskany zbiór wartości współczynnika $n$ (Rys. 4) przybliża łączny efekt wszystkich procesów hydraulicznych wpływających na opory hydrauliczne w przedmiotowym kolektorze podczas prowadzenia pomiarów (Tab. 2).

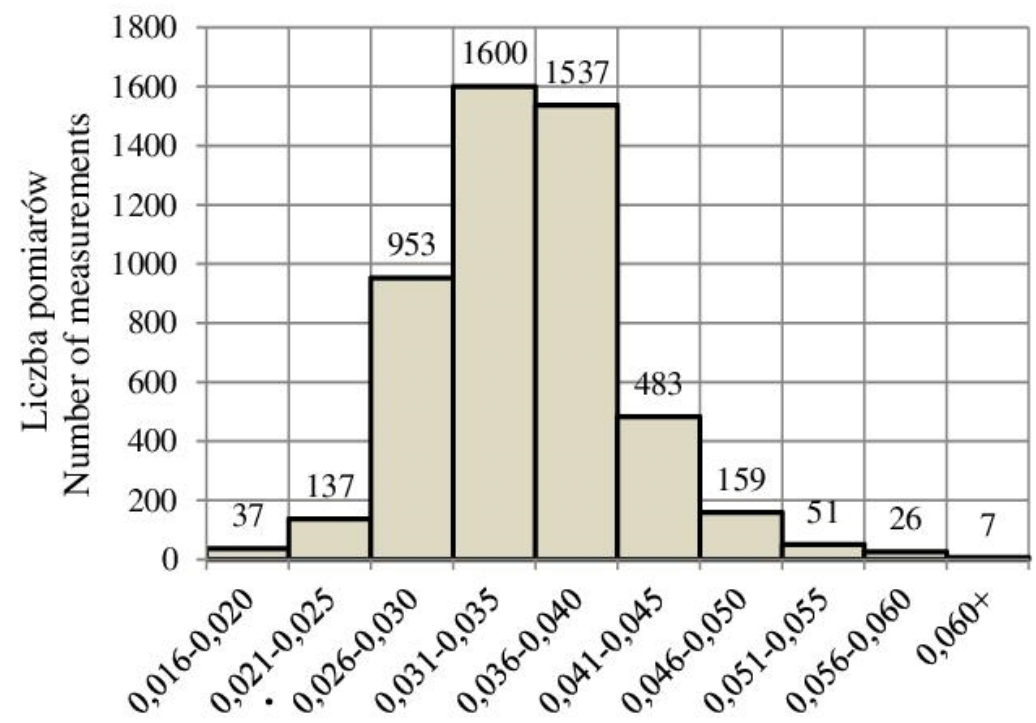

Rys. 4. Histogram współczynnika $n$ w kolektorze z osadem

Fig. 4. Histogram of $n$ coefficient in sewer with sediment 
Charakterystyczne parametry hydrauliczne zestawiono w Tabeli 2.

Tabela 2. Parametry hydrauliczne

Table 2. Hydraulic parameters

\begin{tabular}{|c|c|c|c|}
\hline $\begin{array}{c}\text { Parametr } \\
\text { statystyczny }\end{array}$ & $\begin{array}{c}\text { Liczba } \\
\text { Reynoldsa } \boldsymbol{R} \boldsymbol{e}\end{array}$ & $\begin{array}{c}\text { Liczba } \\
\text { Freuda } \boldsymbol{F r}\end{array}$ & Współczynnik $\boldsymbol{n}$ \\
\hline Minimum & 78043 & 0,083 & 0,016 \\
\hline $\begin{array}{c}\text { Średnia } \\
\text { arytmetyczna }\end{array}$ & 206818 & 0,396 & 0,0345 \\
\hline Maksimum & 775184 & 0,672 & 0,064 \\
\hline
\end{tabular}

Jak widać z Tabeli 2 liczby $F r$ zmieniają się w szerokim zakresie, co wskazuje na tendencje tworzenia się zmarszczek i wydm w przebadanym zakresie zmienności. Potwierdzają to obserwacje eksploatacyjne pojawiania się w kolektorze wysokich wydm złożonych $\mathrm{z}$ ciał włóknistych i cząstek ziarnistych widocznych przy niskich napełnieniach ścieków w badanym kolektorze.

Najlepiej dopasowaną do zbioru danych pomiarowych wartość współczynnika $n_{d}$ we wzorze Manninga wyznaczono metodą iteracyjną minimalizując względny średniokwadratowy błąd resztowy BSR (funkcję kryterialną):

$$
B S R=\frac{100 \%}{\overline{V_{p}}}\left(\frac{1}{k} \sum_{i=1}^{k}\left(\left(V_{p, i}-V_{m, i}\right)^{2}\right)^{1 / 2}\right.
$$

gdzie: $\bar{V}_{p}$ - średnia arytmetyczna pomierzonych wartości prędkości przepływu ścieków $[\mathrm{m} / \mathrm{s}]$;

$V_{p, i}$ - pomierzona i-ta wartość prędkości przepływu ścieków $[\mathrm{m} / \mathrm{s}]$;

$V_{m, i}-$ obliczona i-ta wartość prędkości przepływu ścieków [m/s].

Dla oszacowanej optymalnej wartości $n=0,03$ obliczono ze wzoru Manninga napełnienia i odpowiadające im prędkości przepływu (Rys. 5).

$\mathrm{Na}$ rysunku 6 przedstawiono z kolei równanie regresji między współczynnikiem „n” a liczbą Reynoldsa.

Pozostałe przeanalizowane statystycznie zależności opisują równania regresji (12-13):

$$
\begin{aligned}
& n=0,023\left(\frac{L_{1}}{L_{2}}\right)^{-0,506}\left(r=0,43, r^{2}=0,186, t=33,8\right) \\
& n=n_{\text {oss }} 0,4426\left(\frac{h_{s}}{1,8-H_{\text {os }}}\right)^{-0,533}\left(r=0,49, r^{2}=0,24, t=39,8\right)
\end{aligned}
$$

gdzie: $n$ - współczynnik oporów Manninga $\left[\mathrm{s} / \mathrm{m}^{1 / 3}\right]$;

$R e$ - liczba Reynoldsa; 
$\mathrm{L}_{1}$ - długość zwilżonych ścianek kolektora [m];

$\mathrm{L}_{2}$ - szerokość osadu dennego [m];

$\mathrm{n}_{\text {oss }}$ - średni współczynnik szorstkości Manninga $\left[\mathrm{s} / \mathrm{m}^{1 / 3}\right]$;

$\mathrm{h}_{\mathrm{s}}$ - napełnienie kolektora $\mathrm{z}$ osadem $[\mathrm{m}]$;

$\mathrm{H}_{\mathrm{os}}$ - odległość między powierzchnią osadu a stropem kolektora [m].

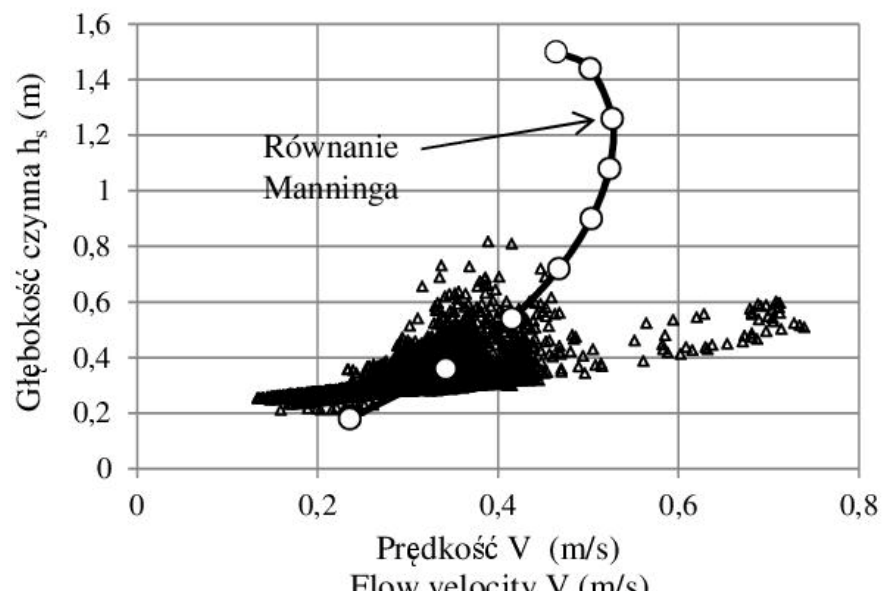

Flow velocity $\mathrm{V}(\mathrm{m} / \mathrm{s})$

Rys. 5. Zależność $h_{s}=\mathrm{f}(V)$ dla $D=1,8 \mathrm{~m}, h_{o s}=0,3 \mathrm{~m}, n=0,03$

Fig. 5. Relationship $h_{s}=\mathrm{f}(V)$ for $D=1,8 \mathrm{~m}, h_{o s}=0,3 \mathrm{~m}, n=0,03$

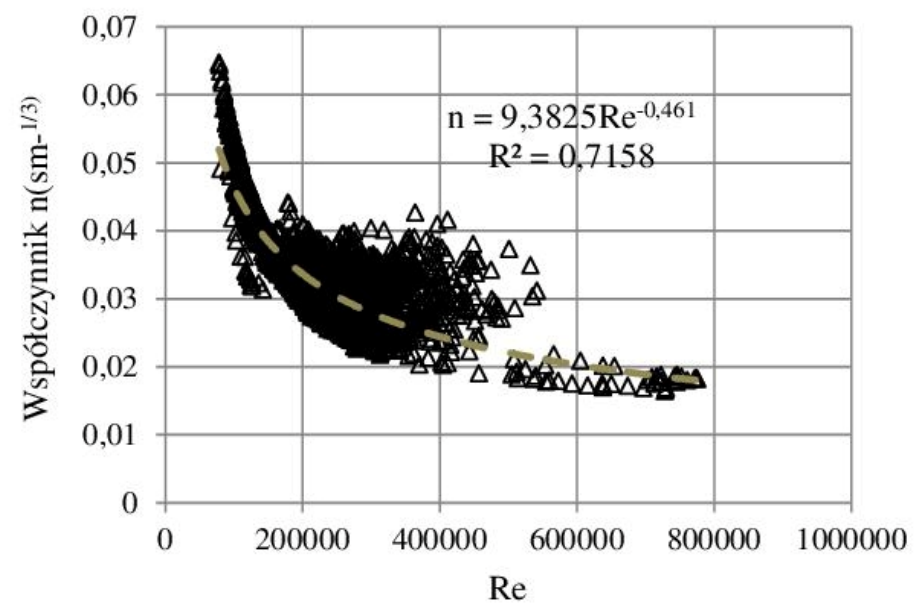

Rys. 6. Zależność między współczynnikiem Manninga $n$ i liczbą $R e$

Fig. 6. Relationship between $n$ Manning's coefficient and Re number 
Hipotezę o zerowej korelacji we wzorach (12-13) na poziomie istotności 1- $\alpha=0,95$ należy odrzucić i przyjąć alternatywną, że analizowane współczynniki korelacji dla populacji generalnej różnią się istotnie od zera.

Należy zauważyć, że relatywnie niskie wartości współczynników determinacji w równaniach regresji (12-13) wskazują, że stopień, w jakim równania regresji wyjaśniają kształtowanie się zmiennej objaśnianej $n_{o s}$ należy ocenić jako słaby. Do oceny wpływu osadu na sprawność hydrauliczną (Tab. 7) przyjęto wartość $n_{o s}=0,02$ obliczoną ze wzoru (13).

Tabela 3. Wpływ miąższości osadu na sprawność hydrauliczną badanego kolektora

Table 3. Influence of sediment depth on hydraulic performance of studied trunk sewer

\begin{tabular}{|c|c|c|c|}
\hline $\begin{array}{c}\text { Względna grubość } \\
\text { osadu dennego } \\
\mathbf{h}_{\mathbf{0 s}} / \mathbf{D}[-]\end{array}$ & $\begin{array}{c}\text { Współczynnik } \\
\text { geometryczny } \\
\boldsymbol{\eta}_{\mathrm{g}} \text { ]-] }\end{array}$ & $\begin{array}{c}\text { Współczynnik } \\
\text { wpływu } \\
\text { szorstkości } \\
\boldsymbol{\eta}_{\mathbf{n}}[-]\end{array}$ & $\begin{array}{c}\text { Sprawność } \\
\text { hydrauliczna } \\
\boldsymbol{\eta}_{\mathbf{h}}[-]\end{array}$ \\
\hline 0,1 & 0,91 & 0,58 & 0,53 \\
\hline 0,2 & 0,77 & 0,58 & 0,45 \\
\hline 0,3 & 0,61 & 0,58 & 0,35 \\
\hline 0,4 & 0,45 & 0,58 & 0,26 \\
\hline 0,5 & 0,31 & 0,58 & 0,20 \\
\hline
\end{tabular}

\section{Podsumowanie}

Przeprowadzone pomiary w czynnym kolektorze o dużej średnicy potwierdziły bardzo silny wpływ osadu dennego na redukcję sprawności hydraulicznej badanego kolektora z osadem.

Parametrami wpływającymi na redukcję sprawności hydraulicznej było zarówno zmniejszenie pola powierzchni przekroju poprzecznego ścieków, jak i wzrost współczynnika oporów Manninga w kolektorze z osadem w stosunku do tych parametrów w kolektorze pozbawionym osadu.

Przeprowadzona analiza danych pomiarowych wskazała na tendencję spadkową oporów hydraulicznych wraz ze wzrostem napełnienia ściekami w przebadanym zakresie napełnienień kolektora $\mathrm{z}$ osadem.

Wyniki pomiarów wskazują na możliwość występowania średnich wartości współczynników Manninga ponad dwukrotnie przewyższających wartości współczynników szorstkości przyjmowanych $\mathrm{w}$ projektowaniu i eksploatacji kolektorów pozbawionych osadu.

Hipotetyczną przyczyną, popartą obserwacjami eksploatacyjnymi tak wysokiej wartości oporów hydraulicznych, jest zapewne nagromadzenie w bada- 
nym odcinku kolektora dużych ciał włóknistych, które z upływem czasu wytworzyły w interakcji z drobnoziarnistą frakcją skonsolidowane formy denne powodujące powstawanie zaburzeń pola prędkości przepływu, które skutkują dynamicznymi zmianami pomierzonej średniej prędkości przepływu.

Fizyczna i biologiczna natura zależności przyczynowo-skutkowych w skomplikowanych układach niestacjonarnego przepływu ścieków w kolektorach z osadem jest bardzo trudna do ilościowego opisu, zwłaszcza gdy w układzie występują sprzężenia zwrotne między procesami sedymentacyjnymi, biologicznego rozkładu osadu, transportem osadu i przepływu hydraulicznego, powodujące, że różne zmienne są dla siebie przyczyną i skutkiem. Wynika stąd, niezależnie od prac nad budową modeli genetycznych, potrzeba prowadzenia badań w czynnych sieciach kanalizacyjnych w celu uzyskania wiarygodnych danych do budowy modeli stochastycznych oraz do weryfikacji parametrów w modelach genetycznych.

Jednym z istotnych warunków prowadzenia pomiarów parametrów osadu w czynnych sieciach kanalizacyjnych jest rozwój metod pomiarowych, a w szczególności automatycznych sond do precyzyjnego pomiaru profili podłużnych osadu zalegającego kanały. Pomiary manualne powinny być prowadzone w zakresie ograniczonym do wstępnej fazy planowania usuwania osadu ze względu na grube błędy pomiarów wykonywanych przy użyciu tej metody.

\section{Literatura}

[1] Bertrand-Krajewski J.L., Gibello C.: A new technique to measure cross-section and longitudinal sediment profiles in sewers, 11th International Conference on Urban Drainage, Edinburgh, Scotland, UK, 2000.

[2] Bertrand-Krajewski J.L., Barraud S., Chocat B.: Need for improved methodologies and measurements for sustainable management of urban water systems, Environmental Impact Assessment Review, vol. 20, 2000.

[3] Bertrand-Krajewski J.L.: Long term monitoring of sewer sediment accumulation and flushing experiment in a man-entry sewer, Water Science \& Technology, vol. 54, 2006, s. 6-7.

[4] Biedrzycka A.: Monitoring krakowskiej sieci kanalizacyjnej, Nowoczesne Budownictwo Inżynieryjne, Listopad - Grudzien, 2015.

[5] Bruaset S., Hem L.J., Ugarelli R.: Water quality sensors micro-location in sewers Definition of methods for optimal micro-location of sensors in sewers, FP7, Prepared 7th Framework Programme, 2011.

[6] Enfinger K.L., Stevens P.L.: Scatter graph principles and practice - Practical application of the Freud Number to flow monitor data, ADS Environmental Services, 2006.

[7] European Benchmarking Co-operation (EBC) - 2015 Water \& Wastewater Benchmark, 2015. 
[8] Kalinowski M.: Wpływ osadu dennego w kolektorze na jego sprawność hydrauliczną, V Międzynarodowa Konferencja Naukowo-Techniczna INFRAEKO 2016, Kraków, 2016, s. 133-153.

[9] Kouyi G.S., Bonakdari H., Bertrand- Krajewski J.L.: Use cfd technique to optimize flowmeters location in sewers, Definition of methods for optimal micro-location of sensors in sewers, FP7, Prepared $7^{\text {th }}$ Framework Programme, 2011.

[10] Lepot M., Pouzol T., Aldea Borruel X., Suner D., Bertrand- Krajewski J.L.: Monitoring sediments in sewer with sonar technology: from laboratory experiments to in situ tests, $13^{\text {th }}$ International Conference on Urban Drainage, Sarawak, Malaysia, 7012 September 2014.

[11] Michalski A., Sienkiewicz J., Wartal Z.: Metody pomiarowe przepływu na małych otwartych kanałach przepływowych, Diagnostyka’3 (39), 2006.

[12] NEL National Measurement System - Good Practice Guide: Flow measurement uncertainty and data reconciliation, Glasgow, 2000.

[13] Nowogoński I.: Wpływ inwentaryzacji kształtu przekrojów kanałów na dokładność przepływomierza profilującego, Uniwersytet Zielonogórski, Zeszyty Naukowe Nr 145, Inżynieria Środowiska Nr 25, 2012.

[14] Piechurski F.G.: Próba oceny metod i urządzeń do pomiaru przepływu ścieków, Napędy i Sterowanie, Nr 5, 2011.

[15] Ribeiro S.A., Ceu Almeida M.C., Palma J.: Uncertainty evaluation of multi- sensor flow measurement in a sewer system using Monte Carlo method, XIX UMEKO World Congress, Fundamental and Applied Metrology, Lisbon, Portugal. 2009.

[16] Staufer P., Dettmar J., Pinnekamp J.: Improvement of water quality by sewer network flushing, Novatech, Session 6.3, 2007.

[17] Stevens P.L., Kimbrough H., Enfinger K.: Be wary of weally wough waves, WEF Collection Systems, 2004.

[18] Synowiecka J., Burszta- Adamiak E., Konieczny T., Malinowski P.: Pomiary na czynnych sieciach kanalizacji deszczowej i ogólnospławnej, Inżynieria Ekologiczna, vol. 39, 2014.

[19] Teufel M., Solliec L.: Investigation of the Nivus flow rate sensor, Definition of methods for optimal micro-location of sensors in sewers, FP7, Prepared $7^{\text {th }}$ Framework Programme, 2011.

[20] Velasco M., Suner D., Bertrand -Krajewski J.L.,Aldea X.,Pouget L.: Development of technical guidelines for the monitoring and modelling of sediments, Report number: 2013.003, Seventh Framework Programme, 2013.

[21] Williams K.J.: In- sewer sedimentation associated with active flow control, $11^{\text {th }}$ International Conference on Urban Drainage, Edinburgh, Scotland, 2008.

[22] Wożniak R., Osiński A.: Monitoring sieci kanalizacyjnej w Gdańsku, Wodociągi i Kanalizacja, 51511, 2008.

[23] Wymagania dotyczące realizacji stacjonarnych układów pomiarowych przepływu ścieków w przewodach otwartych, Miejskie Przedsiębiorstwo Wodociągów i Kanalizacji S.A. w Krakowie, Wersja 3, F4-\%-13, 2014. 
[24] Wytyczne do opracowywania dokumentacji technicznych oraz budowy przewodów i przyłączy wodociągowych i kanalizacyjnych oraz przepompowni kanalizacyjnych, Załącznik Nr 3 : Punkty pomiarowe na sieci wodociągowej i kanalizacyjnej, Miejskie Przedsiębiorstwo Wodociągów i kanalizacji w Warszawie, 2015.

[25] Xin G., Bertrand-Krajewski J.L.: A unified protocol for sensor calibration and verification in applications to WWTPs and sewer system monitoring, Water Pollution XI. 2012.

\section{PROBLEMS OF WASTEWATER FLOW AND SEDIMENT DEPTH MONITORING IN MAN - ENTRY TRUNK SEWER PIPES}

\section{S u m m a r y}

The main subject of this paper is justification of the need for including measurements of sewer sediment depth into monitoring of the sewer networks and demonstrate the technical problems with flow and sediment depths measurements in man entry sewers. The possible improvements of sediment monitoring in sewer network have also been shown on the basis of literature review. The paper covers the impact of an measurement error of sediment depth on the sediment and wastewater flow cross section area estimation. The assessment of the impact of bottom sediment on flow capacity of $1800 \mathrm{~mm}$ in diameter sewer pipe has been provided.

Keywords: field measurements, roughness coefficients, Manning formula, rate of flow, flow velocity, sediment thickness, measurement uncertainty.

DOI:10.7862/rb.2016.156

Przestano do redakcji: 01.05.2016 $r$.

Przyjęto do druku: 28.06.2016 r. 